\title{
Development of students' views on the demarcation between science and pseudoscience
}

\author{
Ali Biçer \\ Mersin University, Institute of Education Sciences, Mersin, Turkey, alibicer3344@gmail.com \\ Feride Ercan Yalman \\ Mersin University, Faculty of Education, Department of Science Education, Mersin, Turkey, \\ feride.edu@gmail.com
}

\begin{abstract}
This research aimed to determine and develop $8^{\text {th }}$ grade students' views on the demarcation between science and pseudoscience. In this context, the study was designed with convergent parallel design which is a mixed research method. The study group for the quantitative dimension was composed of 328 th graders in a secondary school in Akdeniz district of Mersin province. The study group for the qualitative dimension consisted of six students selected from among these 32 students by purposeful sampling method. As data collection tools, Pseudoscience Belief Scale which consisted of 21 questions and a semistructured interview form composed of nine questions were used. During the data analysis, statistical calculations were done by using the SPSS package program for the quantitative dimension. Content analysis method was used to categorize qualitative as codes and themes. Based on the study results, it was observed that the pseudoscientific beliefs were not based on gender and it was found that students' pseudoscientific beliefs decreased with the implementation in which the argumentation method was used.
\end{abstract}

Keywords: Argumentation, Pseudo-science, Science

\section{Öğrencilerinin bilim sözde-bilim ayrımına ilişkin görüşlerinin geliştirilmesi}

ÖZ Bu çalışmada sekizinci sınıf öğrencilerinin bilim ve sözde-bilim ayrımına ilişkin görüşlerinin tespit edilmesi ve bu görüşlerinin geliştirilmesi amaçlanmıştır. Bu bağlamda çalı̧̧ma, karma araştırma yöntemlerinden yakınsayan paralel desene göre düzenlenmiştir. Araştırmanın nicel boyutunun çalışma grubunu Mersin ili Akdeniz ilçesinde yer alan bir ortaokuldaki sekizinci sınıf düzeyinde öğrenim gören 32 öğrenci oluşturmaktadır. Araştırmanın nitel boyutunun çalışma grubu ise 32 öğrenci arasından amaçlı örneklem yöntemiyle seçilen altı öğrenciden oluşmaktadır. Veri toplama araçları olarak 21 sorudan oluşan Sözde-Bilim İnanış Ölçeği ve dokuz sorudan oluşan yarı yapılandırılmış görüşme formu kullanılmışır. Veri analizinde nicel boyut için SPSS paket programı kullanılarak istatistiksel hesaplamalar yapılmıştır. Nitel veriler ise içerik analizi yöntemiyle kodlar ve temalara ayrılmıştır. Çalışma sonucunda sözde-bilimsel inanışların cinsiyet faktörüne bağlı olmadığı ve argümantasyon yönteminin kullanıldığı uygulama ile öğrencilerin sözde-bilimsel inanışlarında azalma meydana geldiği görülmüştür. Ayrıca cinsiyet faktörüne bağlı olmaksızın uygulama öncesi öğrencilerin bilim ve sözdebilime yönelik fikir ve bilgilerinin, uygulama sonrasında kısmen değiștiği ve geliştiği görülmüştür.

Anahtar

Sözcükler: Argümantasyon, Bilim, Sözde-bilim

\section{Citation: $\quad$ and pseudoscience. Turkish Journal of Education, 10(3), 211-236.}

https://doi.org/10.19128/turje.907117 


\section{INTRODUCTION}

Today, science is one of the most distinct indicators that demonstrate the level of development in countries. Now we have reached a stage where science education is necessary and compulsory for societies to ensure the continuity of development (Soslu, 2014). What science is and how it is supposed to be should be comprehended well before teaching science. However, there is no agreement on these two questions yet (Çetinkaya et al., 2015). This state is explained by the fact that science, by its nature, has a variable and comprehensive structure (Afonso \& Gilbert, 2010).

There is no clear and agreed upon definition of science. For example, according to McComas (1998), science is an activity undertaken to reveal valid and reliable generalizations and explanations that are open to everyone to use by using scientific research methods to answer questions about the natural world. According to Einstein (1940), science is an effort to ensure compatibility between sensory data (perceptions) devoid of any order and logical regular thinking. Russell (1997), on the other hand, defines science as an effort to find out the facts about the world through observation and reasoning based on observation and then to discover the laws that connect these facts. In national literature, Y1ldirim (2010, p.16) regards science as "not a frozen, stationary topic, but an activity that develops and changes at a constant and increasing pace", while Topdemir (2002, p. 45) confines science as "knowledge with certain qualities." Şahin (2006) regards science as the effort of human beings to research the phenomena of nature and society with certain methods and to produce systematic information. Despite the existence of many definitions, there is still no clear conclusion about which explanations should be accepted scientifically (Lambert \& Brittan, 2011). Therefore, it is difficult to distinguish between scientific and non-scientific information. Approaching a thought or research as if it were scientific attracts people's attention to that subject and can cause them to value it more. The fact that science is highly valued has also brought pseudoscientific fields or beliefs under the name of science. In this context, pseudoscience can be defined as all the propositions, practices and attitudes arranged according to a certain logic that seems scientific (Martin, 1994). On the other hand, pseudoscience that gives the impression of actually possessing scientific norms is regarded as the body of unfounded thoughts (Tutar, 2014) that replicate the process and terminology of science that cannot be revised within the scope of new scientific information and that cannot contribute to scientific research. Today, topics such as astrology, numerology, grafology, reflexology, UFO, healing stones, homeopathy, reincarnation and parapsychology are examples of pseudo-scientific beliefs which are presented on popular media and can influence large audiences (Liu, 2009). Many studies in the literature reveal that pseudoscientific beliefs are widely accepted in societies and there is a high rate of inability in distinguishing pseudoscience from science (Johnson \& Pigliucci, 2004; Sugarman et al., 2011). In addition, some research reported an increase in students' pseudoscientific beliefs in recent years (Shein et al., 2014; Tseng et al., 2014). According to Tutar (2014) relevant research links these widespread perceptions and increasing beliefs in pseudoscience to the use of language preferred by pseudo-science that seems deceptive and scientific. The researcher even states that this misleading language can easily canalize educated people at all levels. In the same vein, Martin (1994) states that the technical language, complex arguments and a series of journals and texts that give people the assumption that pseudoscience is scientific provide the foundation for an atmosphere that sounds scientific, thus facilitate the actors and sectors in pseudoscience. In this respect, distinguishing between the scientific from the non-scientific is of great importance. In this context, Popper (2002, p. 66) suggests the criterion of falsifiability while Kuhn (1996) suggests the paradigm among the criteria of science. Lakatos $(2014$, p.121) finds in distinguishing between science and pseudoscience inadequate and claims that scientific research programs should evaluate a series of theories, not a single theory. Sönmez (2008, p.175) argues that scientific propositions are testable, falsifiable, and confutable. In distinguishing between scientific and pseudoscientific information, some researchers developed various criteria by expressing the issues they consider to be important. For example, according to Wynn and Wiggins (2008), while scientific observations or explanations arise from real events; pseudoscientific observations do not contain reality (cited in: Arık \& Akçay, 2018, p. 
5). According to Bunge (2011), the following can be used to distinguish between science and pseudoscience: pseudoscience includes inconsistent and ambiguous ideas, it is not based on existing scientific findings and pseudoscientific statements violate the basic principles of science. However, it is also stated that the criteria identified for distinguishing between science and pseudoscience are insufficient and the scientific world will have difficulties in dealing with pseudoscientific information in a logical manner within the scope of these insufficient criteria and difficulties in regards to definitions (Efthimiou \& Liewellyn, 2006). The reason why pseudoscience is partly advantageous over science in the struggle between science and pseudoscience can be explained with a number of arguments. First; pseudoscience uses an easier and more understandable language for society, while the scientific language is more complicated. This does not arise from the weakness of science but is rather related to the comprehensive nature of science. Secondly, pseudoscience can benefit from science when it is possible by using the data produced by science in a way that supports its own claims. However, it is not possible for science to benefit from pseudoscience in this manner. Thirdly, the capacity of human beings that will help distinguish between science and pseudoscience and their insufficient field knowledge are thought to be effective in pursuing pseudoscientific beliefs. Kirman Çetinkaya et al. (2013) suggested that these three obstacles can be overcome by emphasizing scientific literacy and that science /pseudoscience distinction can be made with the help of scientifically literate individuals.

The concept of scientific literacy was first used by Paul Hurd and McCurdy in 1958 (as cited in: Kaya \& Bacanak, 2013). One of the important features that scientifically literate individuals should have is the ability to distinguish the scientific from the unscientific in addition to having knowledge about the sub-dimensions of science (Norris \& Phillips, 2003). Scientific literacy is regarded to be very important for distinguishing between science and pseudoscience. Science is of great importance not only for scientists but even for non-scientists (Russell, 1997). In this context, science education should not only aim to teach scientific facts but it should be effective in learning and doing science in addition to evaluating the value, strength and limitations of scientific knowledge (Turgut et al., 2010). Science education programs are organized from this perspective. For the first time in Turkey, the 2005 "Science and Technology Curriculum" vision stated the goal is to train all students to be scientifically literate regardless of individual differences (Ministry of National Education [MoNE], 2005). The curriculums prepared after 2005 also targeted to provide science education from which scientifically literate individuals can benefit in their daily lives and professional careers. Science literacy, which is generally considered to be the same as scientific literacy, is regarded to be an important factor in providing societies with a scientific perspective. Science literate individuals are expected to contemplate new explanations with a questioning perspective when they make decisions about personal and social issues. Argumentation process must be experienced first in order for these cognitive competencies and judgments to take place since argumentation is the process of making claims valid by making justifications and supporting them by data. In other words, argumentation is an activity or discussion to reach logical decisions to explain the contrast between the two opposite situations (Kaya \& Kılıç, 2008). In addition, the necessity of using argumentation process in science education is supported by the fact that science education based on the argumentation process equips individuals with the ability to scientifically examine daily events and scientific studies and to think about these circumstances in a scientific manner. In this context, it can be said that using the argumentation method in interesting contexts and scenarios will be an important method to distinguish between science and pseudoscience (Arık \& Akçay, 2018). It is believed that examining contradictions with the help of argumentation, presenting knowledge claims and looking at the situation in a holistic way with the help of rationales and confutations may be possible when making distinctions between scientific and non-scientific information. In addition to the mentioned benefits of argumentation, Osborne et al. (2004) state that argumentation-based teaching is a discourse that allows students to improve their knowledge-related practices. For these reasons, this study utilized learning activities based on argumentation to develop awareness of science and pseudoscience distinction in students.

Relevant studies in literature that address pseudoscience (Gül, 2016; Impey et al., 2012; Losh \& Nzekwe, 2011; Tsai et al., 2015) show that the target groups were generally adults and university students. Studies with high school students and studies to identify the pseudo-scientific beliefs of 
students at different grade levels (Afonso \& Gilbert, 2010; Kallery, 2001) are also available in literature. Regardless of the age group, studies pointed to the existence of pseudoscientific beliefs in most of the students as a common finding. In addition to these studies in international literature; Martin's (1994) research on the effects of pseudoscience on science students and McLean and Miller's (2010) study to reduce students' paranormal beliefs and develop critical thinking skills are also among the relevant studies. Turgut (2009) examined teacher candidates' views on the distinction between science and pseudoscience, while Kaplan (2014) focused on teacher candidates' views on the distinction between science and pseudoscience with regards to astrology and astronomy. Ayvacı and Bağ (2016) examined classroom teacher candidates, Ağlarcı and Kabapınar (2016) studied chemistry teacher candidates and Gül (2016) examined biology, physics and chemistry teacher candidates on their views on the sciencepseudoscience distinction. Çekbas (2017) explored the effect of argumentation-based astronomy teaching on science teacher candidates' beliefs on the nature of science, pseudoscience and epistemology while Şenler and İrven (2016) presented the effect of the elementary teacher candidates' epistemological beliefs on their pseudoscientific beliefs. In addition, literature review points that there are two scale development studies identifying pseudoscientific beliefs (Çetinkaya \& Taşar, 2018; Kirman Çetinkaya et al., 2013). Literature also includes studies to improve both students' and teacher candidates' ability to distinguish between science and pseudoscience (Çekbaş, 2017; Turgut et al., 2010). Furthermore, albeit limited, there are assessment studies addressing the science-pseudoscience demarcation at secondary school level and studies in which a curriculum or application is included along with assessment (Arrk, 2016; Metin, 2015). These studies were mainly conducted with the qualitative research approach. This research was carried out with mixed research design was conducted on a sample (8th grade) that had been rarely studied before in regards to the distinction between science and pseudoscience. Some studies in literature examining the science and pseudoscientific distinction in terms of the gender variable concluded that this distinction was not based on gender (Berkant \& Ermeydan, 2017; Gül, 2016; Lundström, 2007; Şahin \& Uçar, 2018). On the other hand, gender was found to be effective in some pseudoscientific issues such as astrology (Losh \& Nzekwe, 2011; Williams et al., 2007). In other words, literature presents different results for the relationship between the gender variable and the distinction between science and pseudoscience. For this reason, gender dimension was included to be examined as a sub-problem within the scope of this study.

Based on the general evaluations of the studies in literature, it can be argued that especially in the last decade, the national literature has focused on the subject of distinguishing science from pseudoscience. In addition, it was observed that the majority of the participants in these studies both in national and international literature were composed of secondary and higher education students while elementary school students were rarely included in the study groups (Ağlarc1 \& Kabapınar, 2016; Ayvac1 \& Bağ, 2016; Lundström, 2007). It can be stated that especially the studies conducted with teacher candidates focused on assessing the current situation in regards to distinguishing between science and pseudoscience. It was also observed that these studies were designed with either quantitative or qualitative research methods.

The present study, which aimed to analyze pseudoscientific beliefs in depth and to develop the pseudoscience-science distinction through argumentation, was carried out with $8^{\text {th }}$ grade students by using a mixed method. This study is believed to contribute to relevant literature. The problem statement in this study included four sub-dimensions; (i) Is there a significant difference based on gender in the scores obtained from the Pseudoscience Belief Scale, applied before and after the argumentation-based instruction?, (ii) Is there a significant difference between students' pre and post instruction scale scores in terms of students' ability to distinguish between science and pseudoscience in the study in which the argumentation method was used? (iii) What are the students' views regarding the scientific knowledge during the first interview and the final interview? and (iv) What are the students' views on pseudoscience during the first interview and the final interview? 


\section{METHOD}

Convergent parallel design, a mixed research method, was used in this study. The convergent design is a mixed method design in which both quantitative and qualitative data are collected at the same time and analyzed and combined separately (Creswell \& Plano Clark, 2018). In this pattern, data is collected and analyzed simultaneously. The present study simultaneously collected different but complementary data on the same subject and combined two data forms. During this process, it is expected that the data will complement each other and confirm or reveal the differences, if any. For this reason, the study followed the convergent parallel design.

\section{Participants}

The quantitative dimension of this study included $328^{\text {th }}$ grade students in a secondary school in the Akdeniz district of Mersin. The study group, selected with convenience sampling method, was composed of the students (18 male, 14 female students) in Science Applications Course taught by the first researcher at the school where he was working. The convenient sampling method was thought to be practical to be used in the study and enabled the research process to be carried out more reliably (Yıldırım \& Şimşek, 2016).

The qualitative dimension of this study included six students. Three of the students selected via purposeful sampling method were female and the other three were male students. In purposeful sampling, the researcher selects individuals and environments for a specific purpose (Creswell, 2017). The participants to be interviewed were selected according to the criterion sampling method, a subdimension of the purposeful sampling method. The criterion in this study was obtaining the lowest and highest score in the scale during the pre-implementation process for the quantitative dimension. It was aimed to gather in-depth data by conducting interviews with three students (Two male, one female) who got the highest scores and three students (one male, two female) who received the lowest scores from the scale. During the interviews, the participant consent was obtained and interviews were conducted on a voluntary basis. In addition, parents were informed about the research process and their consent was obtained.

\section{Instruments}

Pseudoscience Belief Scale (PBS) developed by Çetinkaya and Taşar (2018) was used in the quantitative dimension of the study with permission. The 5-Likert scale consists of 21 questions with three subdimensions: pseudo-physical, pseudo-predictive and pseudo-medical. PBS was implemented twice in the study: before and after the argumentation-based teaching process. The highest score that can be obtained from each scale item is 5 and the lowest score is 1 . While the highest score that can be obtained from the scale is 105 , the lowest score is 21 . In addition, high scores obtained from the scale correlated with higher belief in pseudoscience, while low scores show that lower belief in pseudoscience. In other words, it is desirable to obtain low scores from the scale in question.

Semi-structured interview form was used as a data collection tool in the qualitative dimension of the study. The interview form approach utilizes a list of questions to ensure in-depth examination during the interview (Yıldırım \& Şimşek, 2016). The number of questions in the interview form was increased from 5 to 9 and necessary adjustments were made in the interview form was prepared with 5 open-ended questions based on the feedback received from the experts and taking PBS sub-dimensions into consideration. Appendix A presents the interview form used in the present research. The students were audio-recorded with their permission when they were interviewed. The interviews took approximately 15 minutes.

\section{Implementation}

This study, which aimed to identify and develop perceptions regarding science and pseudoscience 
distinction, used the argumentation method in four different contexts. Prior to instruction based on argumentation, PBS was given to the study group selected at the beginning of the study. The students were ranked according to the scale scores they received before instruction. Among these students, three students with the lowest score and three students with the highest score were identified. The semistructured interview form was given as a preliminary interview to these six students. After analyzing the data collected at this stage, four level-appropriate topics (healing stones, reflexology, astrology and ufology) were discussed using the argumentation method for four weeks, two lessons per week. Each week, one of these topics was discussed in the classroom environment with the argumentation method. The implementation process lasted a total of six weeks. In line with the argumentation method, the students who were divided into groups before each discussion were given an argumentation form and after they were asked to fill the form after reading the pseudo-science texts. Appendix B presents the pseudo-science texts used in this study. In the forms, students were requested to determine the scientific and non-scientific information in the texts and discuss their reasons in writing. Responses provided to the forms were asked to be shared. In this direction, an argumentation process was carried out with the participation of the whole class. The discussions were carried out under the supervision of the teacher and with the participation of different students. The discussions on the pseudoscience texts were included in lesson plans prepared according to the $5 \mathrm{E}$ approach. Appendix $\mathrm{C}$ presents a sample lesson plan. PBS and interview form were applied to the same students again at the end of this period. The data were analyzed after the implementation. Figure 1 presents the implementation process.

\section{Figure 1.}

Implementation Process
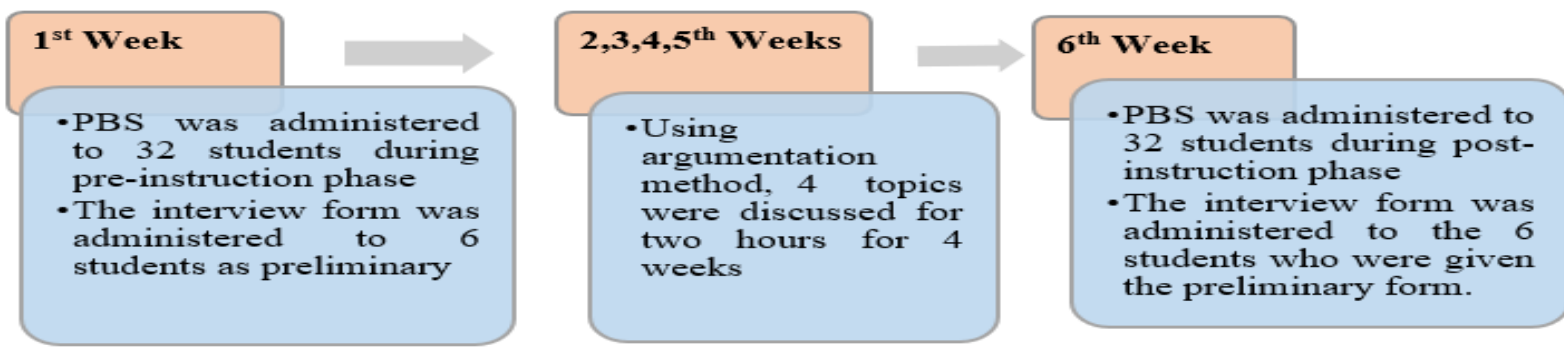

\section{Data Analysis}

Data analysis included statistical calculations using the SPSS 22 package program for both the overall scale and for its sub-dimensions. From parametric tests, independent samples t-test and related samples t-test were used in data analysis. Content analysis method was used in the analysis of qualitative data. The main purpose in content analysis is to determine the relevant concepts in order to explain the data obtained and to establish connections between these concepts (Yıldırım \& Şimşek, 2016). Codes and themes were created with open coding method during content analysis. Also, matrices and figures showing the relations of these codes and themes were prepared.

\section{Validity and Reliability}

The Cronbach's alpha reliability coefficient value of the scale, used in the quantitative dimension of the study with permission, was calculated as .84 by the researchers. In this study, the pilot study of the scale was carried out with $548^{\text {th }}$ grade students in three different secondary schools in Mersin. Cronbach alpha reliability coefficient value was calculated as .88 for the pilot study. Cronbach alpha reliability coefficient is desired to be above .70 on scales used in scientific studies as data collection tools (DeVellis, 2003). The result obtained in the pilot study shows that the scale has a high reliability coefficient. For this reason, it was decided to use the PBS in this study. In the main study, the Cronbach alpha reliability coefficient of the scale, which was applied as a pre-test to 32 students, was calculated as .78. 
Expert opinion was sought after the semi-structured interview form was prepared and necessary adjustments were made based on the feedback received from the experts. The functionality of the questions was tested by piloting the interview form with 10 people. The interviews were recorded as voice recordings with the permission of the volunteer students who were interviewed and their parents. Multiple raters (three raters including the two researchers and one independent rater) participated in the analysis of the interview transcripts within the scope of validity and reliability studies. The percentage of compliance suggested by Miles and Huberman (1994) was found to be $85 \%$ in this study. However, participant confirmation was utilized during the analysis of the transcripts to check the accuracy and integrity of the findings. Participants also confirmed the transcripts. According to Guba and Lincoln (1982), credibility and transferability are as important as validity and reliability in qualitative research. In order to ensure credibility in this study, the researcher and the participants had long-term interaction. Since the first researcher taught science to the study group, she was able to spend a lot of time to understand the student views. Three raters were assigned to prevent possible bias in the qualitative data analysis process. Another method for providing credibility is expert examination. At this stage, the expert critically observed all the processes from the design of the research to the collection, analysis and writing of the results and provided feedback. In order to ensure transferability in the research, attention was paid to describe both the implementation phase and the reporting phase as clearly as possible. In addition, to ensure validity and reliability and provide credibility and transferability, parts of student responses provided in the interviews were presented in the findings section in quotations. Principle of volunteering was taken into consideration during the implementation phase of the research. Ethical rules were followed in the reporting phase in order to ensure confidentiality. In this context, participants' names were not used and they were given codes such as P1, P2. Considering all these processes, it can be argued that no problems are foreseen in the analysis of the data in terms of validity, reliability, credibility, transferability and ethics. Approval for this research was obtained from Mersin University Social and Human Sciences Ethics Committee (8/10/2020-37).

\section{FINDINGS}

\section{Quantitative Findings}

In the first research question, SPSS package program was used for descriptive statistics first to investigate whether there was a significant difference based on gender between the mean scores obtained from the PBS implemented pre and post instruction. Then, independent sample t-test was used to test whether there was a significant difference and the results are presented in Table 1.

Table 1.

Pre-Instruction Pseudoscientific Belief Scale T-Test Results Based on Gender

\begin{tabular}{llcccc}
\hline & $\mathrm{N}$ & Means & SD & $\mathrm{t}$ & $\mathrm{p}$ \\
\hline Female & 14 & 2.72 & .45 & -1.84 & .076 \\
Male & 18 & 3.04 & .52 & & \\
\hline
\end{tabular}

According to Table 1, male students' pre-instruction PBS scores were higher than female students' average scores. In other words, it can be argued that male students' pseudoscience perceptions were higher before teaching. To determine whether this difference was significant, independent samples ttest was conducted to compare female and male students' pre-instruction scores. According to the test results, it can be said that there was no significant difference between the scores obtained from female $(\mathrm{M}=2.72, \mathrm{SD}=.45)$ and male $(\mathrm{M}=3.04, \mathrm{SD}=.52 ; \mathrm{t}=-1.84, \mathrm{p}>.05)$ students. The Eta square statistic (.10) obtained shows a moderate effect size. Independent sample t-test was conducted to test whether there was a significant gender-based difference in the scores obtained from the sub-dimensions of the scale applied pre-instruction. Table 2 presents the results. 
Table 2.

Pre-Instruction Pseudoscientific Belief Scale Sub-Dimensions T-Test Results Based on Gender

\begin{tabular}{lllcccc}
\hline Sub Dimension & Gender & $\mathrm{N}$ & Means & SD & $\mathrm{t}$ & $\mathrm{p}$ \\
\hline Pseudo-physical & Female & 14 & 2.75 & .55 & -1.71 & .098 \\
& Male & 18 & 3.07 & .53 & & \\
Pseudo-predictive & Female & 14 & 2.43 & .79 & -.92 & .363 \\
& Male & 18 & 2.74 & 1.04 & & \\
Pseudo-medical & Female & 14 & 3.07 & .71 & -1.38 & .177 \\
& Male & 18 & 3.40 & .63 & & \\
\hline
\end{tabular}

Table 2 shows no significant difference between the scores obtained from female $(\mathrm{M}=2.75, \mathrm{SD}=.55)$ and male $(\mathrm{M}=3.07, \mathrm{SD}=.53 ; \mathrm{t}(30)=-1.71, \mathrm{p}>.05)$ students according to the results of pseudo-physical sub-dimension. The Eta square statistics (.09) obtained shows a medium effect size. According to the results of pseudo-predictive sub-dimension, no significant difference was found between the scores obtained from female $(\mathrm{M}=2.43, \mathrm{SD}=.79)$ and male $(\mathrm{M}=2.74, \mathrm{SD}=1.04 ; \mathrm{t}(30)=-.92, \mathrm{p}>.05)$ students. The Eta square statistic (.03) obtained shows a small effect size. According to the pseudomedical sub-dimension results, there was not a significant difference between female $(\mathrm{M}=3.07, \mathrm{SD}=$ $.71)$ and male $(\mathrm{M}=3.40, \mathrm{SD}=.63 ; \mathrm{t}(30)=-1.38, \mathrm{p}>.05)$ scores. The Eta square statistic (.06) obtained shows a medium effect size. After the statistical calculations for pre-instruction PBS, descriptive statistical calculations were done for post-instruction PBS. Then, an independent sample t-test was performed to determine whether the difference in question was statistically significant. The results are presented in Table 3.

Table 3.

Post-Instruction Pseudoscience Belief Scale T-Test Results Based on Gender

\begin{tabular}{lccccc}
\hline & $\mathrm{N}$ & Means & SD & $\mathrm{t}$ & $\mathrm{p}$ \\
\hline Female & 14 & 2.61 & .57 & 1.50 & .145 \\
Male & 18 & 2.22 & .78 & & \\
\hline
\end{tabular}

Table 3 shows that post-instruction PBS scores of female students were higher than male students' average scores. In other words, it can be argued that female students' pseudo-scientific beliefs were higher post-instruction. According to the scale results, there was no significant difference between the scores obtained from female $(\mathrm{M}=2.61, \mathrm{SD}=.57)$ and male $(\mathrm{M}=2.22, \mathrm{SD}=.78 ; \mathrm{t}(30)=1.50, \mathrm{p}>.05)$ students. The Eta square statistics (.07) obtained shows a medium effect size. The results obtained from all dimensions separately as a result of the argumentation process are presented in Table 4.

Table 4.

Post-Instruction Pseudoscientific Belief Scale Sub-Dimensions T-Test Results Based on Gender

\begin{tabular}{lllllcc}
\hline Sub Dimension & Gender & $\mathrm{N}$ & Means & SD & $\mathrm{t}$ & $\mathrm{p}$ \\
\hline Pseudo-physical & Female & 14 & 2.76 & .73 & 2.22 & .034 \\
& Male & 18 & 2.18 & .73 & & \\
Pseudo-predictive & Female & 14 & 2.29 & .75 & .91 & .369 \\
& Male & 18 & 2.02 & .83 & & \\
Pseudo-medical & Female & 14 & 2.78 & .68 & .47 & .177 \\
& Male & 18 & 2.61 & 1.20 & & \\
\hline
\end{tabular}

Table 4 points to a meaningful difference in favor of male students between the scores obtained from female $(\mathrm{M}=2.76, \mathrm{SD}=.73)$ and male $(\mathrm{M}=2.18, \mathrm{SD}=.73 ; \mathrm{t}(30)=2.22, \mathrm{p}<.05)$ students based on the pseudo-physical sub-dimension of the scale. The Eta square statistic (.14) obtained shows a large effect size. It can be argued there was no significant difference between the scores obtained from female $(\mathrm{M}=$ $2.29, \mathrm{SD}=.75)$ and male $(\mathrm{M}=2.02, \mathrm{SD}=.83 ; \mathrm{t}(30)=.91, \mathrm{p}>.05)$ based on the pseudo-predictive subdimension results. The Eta square statistic (.03) obtained shows a small effect size. There was no significant difference between the scores obtained from female $(\mathrm{M}=2.78, \mathrm{SD}=.68)$ and male $(\mathrm{M}=$ $2.61, \mathrm{SD}=.68 ; \mathrm{t}(30)=.47, \mathrm{p}>.05)$ based on the pseudo-medical sub-dimension results. The Eta square statistics (.007) obtained shows a small effect size. 
Related samples t-test was performed for both the overall scale and its sub-dimensions according to the second research question in order to analyze whether there was a significant difference between pre and post instruction mean scores. The results are presented in Table 5.

Table 5.

Pre and Post Instruction Pseudoscientific Belief Scale T-Test Results

\begin{tabular}{lccccc}
\hline \multicolumn{1}{c}{ Test } & $\mathrm{N}$ & Means & SD & $\mathrm{t}$ & $\mathrm{p}$ \\
\hline Pre-instruction & 32 & 2.90 & .51 & 3.43 & .002 \\
Post-instruction & 32 & 2.38 & .72 & & \\
\hline
\end{tabular}

Table 5 presents a statistically significant decrease in PBS scores between the pre-instruction $(\mathrm{M}=2.90$, $\mathrm{SD}=.51)$ and post-instruction phases $(\mathrm{M}=2.38, \mathrm{SD}=.72), \mathrm{t}(31)=3.43, \mathrm{p}<.05$. The obtained Eta square statistics (.28) shows a large effect size. Similarly, related samples t-test was performed to compare pre and post-instruction mean scores for PBS sub-dimensions. The results are shown in Table 6.

Table 6.

Pre and Post Instruction Pseudoscientific Belief Scale Sub-Dimensions T-Test Results

\begin{tabular}{lllcccc}
\hline Sub Dimension & & $\mathrm{N}$ & Means & SD & $\mathrm{t}$ & $\mathrm{p}$ \\
\hline Pseudo-physical & Pre-instruction & 32 & 2.93 & .56 & 3.12 & .004 \\
& Post-instruction & 32 & 2.41 & .78 & & \\
Pseudo-predictive & Pre-instruction & 32 & 2.60 & .94 & 2.27 & .031 \\
& Post-instruction & 32 & 2.13 & .80 & & \\
Pseudo-medical & Pre-instruction & 32 & 3.26 & .68 & 2.57 & .015 \\
& Post-instruction & 32 & 2.68 & 1.01 & & \\
\hline
\end{tabular}

Table 6 points to a statistically significant decrease in favor of post-instruction between pre-instruction $(\mathrm{M}=2.93, \mathrm{SD}=.56)$ and post- instruction $(\mathrm{M}=2.41, \mathrm{SD}=.78)$ scores for the pseudo-physical subdimension, $\mathrm{t}(31)=3.12, \mathrm{p}<.05$. The Eta square statistics (.24) obtained indicates a large effect size. It can be argued that there was a statistically significant decrease in favor of post-instruction between preinstruction $(\mathrm{M}=2.60, \mathrm{SD}=.94)$ and post- instruction $(\mathrm{M}=2.13, \mathrm{SD}=.80)$ scores for the pseudopredictive sub-dimension, $\mathrm{t}(31)=2.27, \mathrm{p}<.05$. The Eta square statistic $(.14)$ obtained shows a large effect size. For the pseudo-medical sub-dimension, a statistically significant decrease was observed in favor of post-instruction between pre-instruction $(\mathrm{M}=3.26, \mathrm{SD}=.68)$ and post-instruction $(\mathrm{M}=2.68$, $\mathrm{SD}=1.01)$ scores, $\mathrm{t}(31)=2.57, \mathrm{p}<.05$. The obtained Eta square statistics $(.18)$ shows a large effect size. Table 7 was created to compare the item averages of the scores obtained from the Pseudoscientific Belief Scale implemented before and after the instruction.

Table 7.

Pseudoscientific Belief Scale Item Averages

\begin{tabular}{ccccccc}
\hline Item No & Pre-Instruction & Post-Instruction & & Item No & Pre-Instruction & Post-Instruction \\
\cline { 1 - 3 } 2 & 3.16 & 2.19 & 2.56 & 11 & 2.91 & 2.25 \\
2 & 3.03 & 2.25 & 12 & 2.34 & 1.88 \\
3 & 3.16 & 2.66 & 13 & 2.16 & 2.13 \\
4 & 2.47 & 2.19 & 14 & 3.19 & 2.38 \\
5 & 3.03 & 3.00 & 15 & 2.34 & 1.88 \\
6 & 3.53 & 2.81 & 16 & 2.94 & 2.28 \\
7 & 2.72 & 2.13 & 17 & 3.78 & 2.84 \\
8 & 2.47 & 1.94 & 18 & 3.16 & 2.56 \\
9 & 2.81 & 2.13 & 19 & 3.22 & 2.88 \\
10 & 2.34 & & 20 & 3.00 & 2.44 \\
& & & & & 3.13 & 2.69 \\
\hline
\end{tabular}

When the average pre-instruction scores in Table 7 are examined, it can be stated that 11 items in the scale were above 3 points, but there was only 1 item above 3 points post-instruction. Also, when the mean PBS items were compared pre and post-instruction, it was found that there was an increase in the 
means of only the 4th and 7th items in favor of post-instruction. Table 8 examines the status of students' mean scores to be above average ( 3 points) during pre and post-instruction.

Table 8.

Number of Students above Average Score in Pseudoscientific Belief Scale

\begin{tabular}{lcc}
\hline Gender & Pre-Instruction & Post-Instruction \\
\hline Female & 4 & 3 \\
Male & 10 & 5 \\
Total & 14 & 8 \\
\hline
\end{tabular}

Analysis of Table 8 is shows that four female and ten male students were above the average score based on the pre-test score while three female and five male students were above the average score based on the post-test score.

\section{Qualitative Findings}

The interviews conducted to determine $8^{\text {th }}$ grade students' opinions about the science/pseudoscience distinction were transcribed and the content analysis method was used in the analysis of the data obtained. Codes and themes were created for through content analysis. In addition, Figures were prepared to display the relations of these codes and themes. The frequency of using the codes specified in the figures is indicated in brackets. The first three questions were prepared in line with the scientific knowledge main theme in the interviews conducted prior to instruction based on argumentation. Figure 2 was created according to student answers.

\section{Figure 2.}

Preliminary Interview Findings on Scientific Knowledge Main Theme

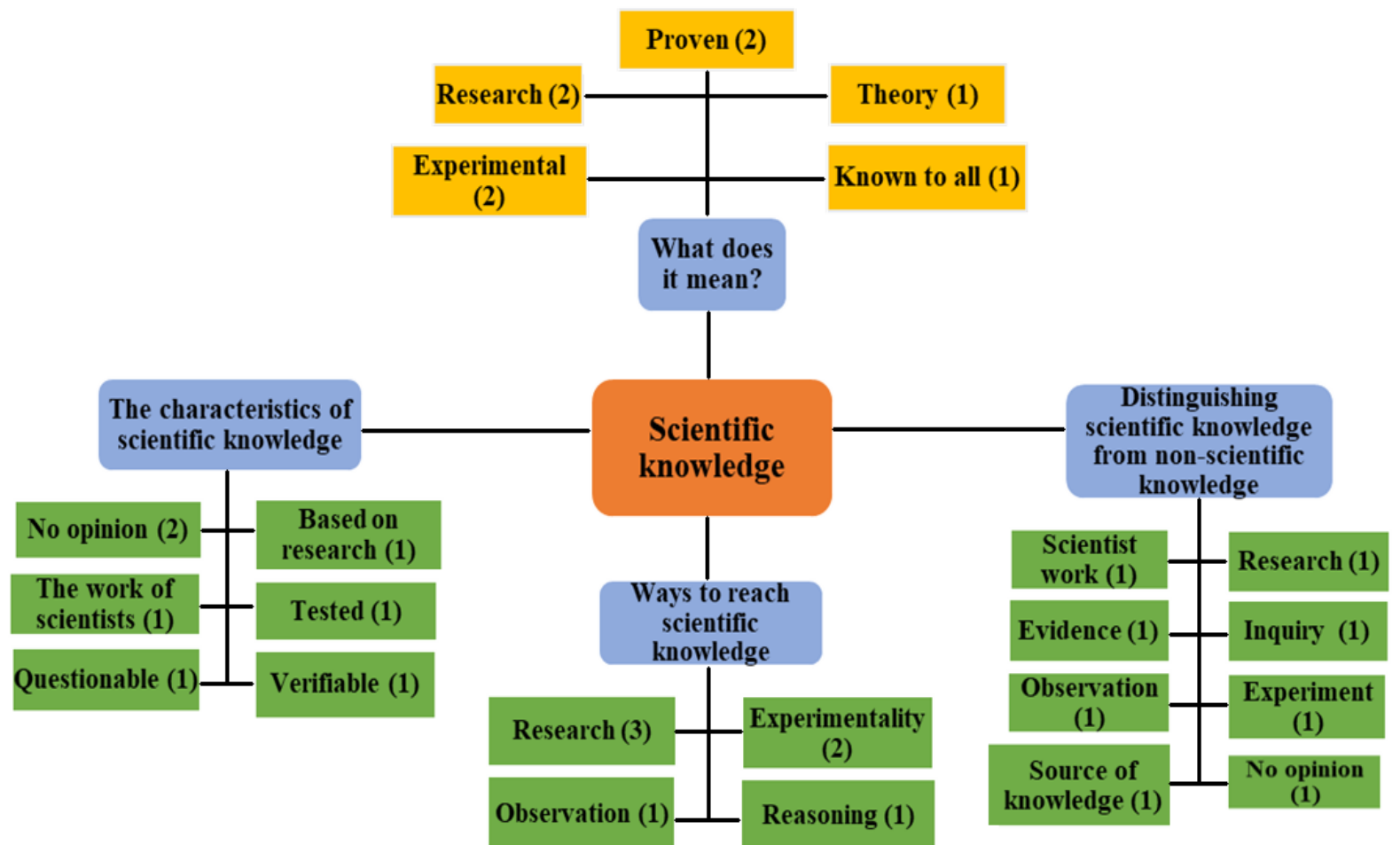

Figure 2 demonstrates that students regard scientific knowledge as experiments, research and proven knowledge. One of the participant's responses about what scientific knowledge means is as follows;

P3: "Proven, tested and conclusive knowledge." 
The characteristics of scientific knowledge in Figure 2 shows that two students had no opinion and scientific knowledge was regarded as the product of scientists, research and experimentation. When students were asked about the ways of obtaining scientific information, their answers focused on research and experiment as the most commonly used methods. Although there was no prominent code in regards to distinguishing scientific knowledge from non-scientific knowledge; methods such as experiments, research and observation were cited again. Figure 3 was created based on the student views in the final interview form for the scientific knowledge main theme.

Figure 3.

Final Interview Findings on Scientific Knowledge Main Theme

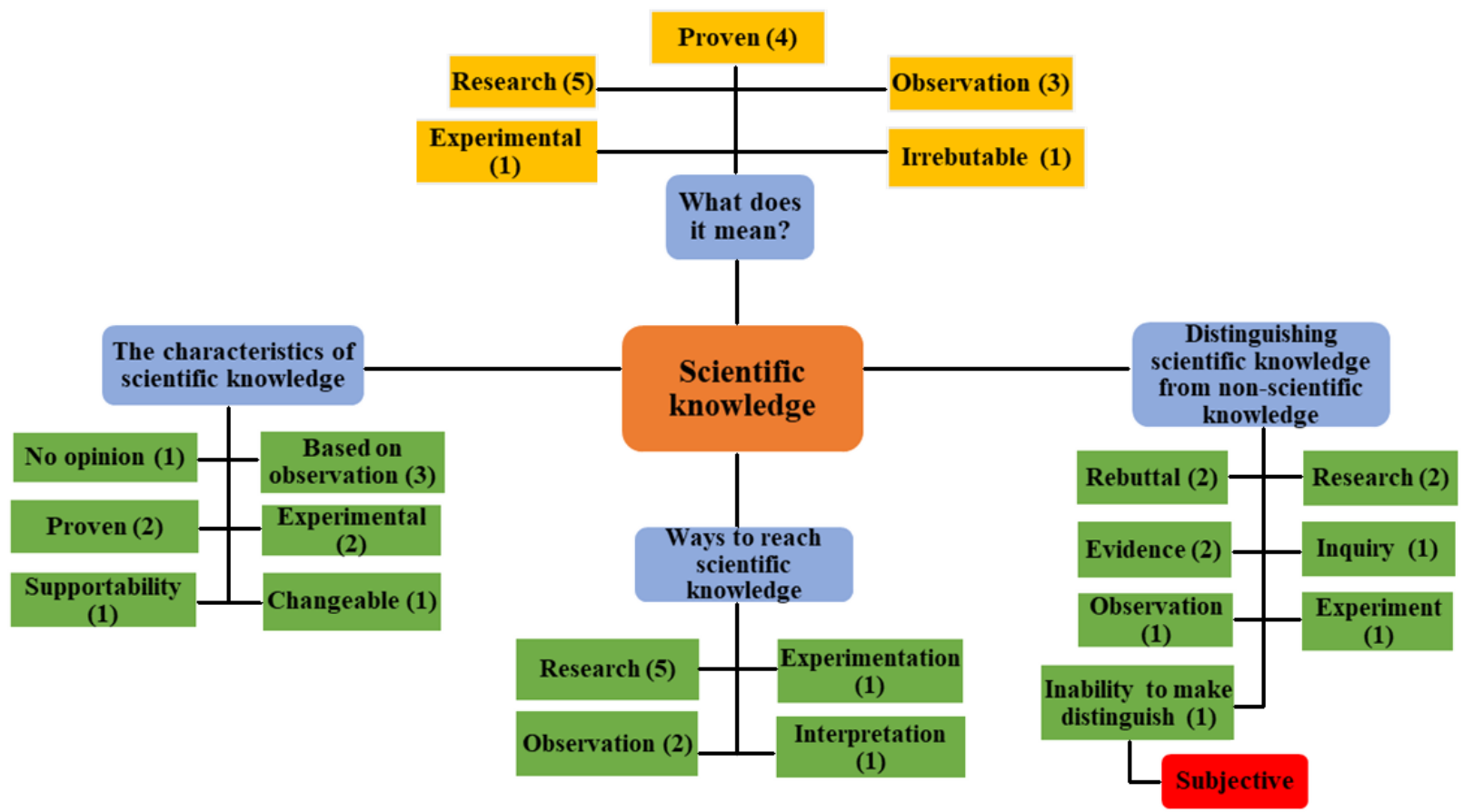

When Figure 3 was examined, it was observed that scientific knowledge generally meant research, observation and proof for students. It was noted that the concept of observation was used in the final interview although it was not included in the preliminary interview. Some of the responses in this regard are presented below.

\section{P4: "Proven knowledge. Knowledge obtained through research and observations."}

\section{P6: "Knowledge obtained as the result of research and observations."}

Figure 3 demonstrates that students used the codes of "based on observation; demonstrability and experimentation" more frequently. Research and observation were found to be at the forefront when they talked about the ways to access scientific knowledge. Compared to the preliminary interview, there was no difference in the answers on this subject. In addition, students mentioned the use of research, evidence and rebuttal in distinguishing between scientific and non-scientific knowledge. Figure 4 was created according to the answers provided by students to the questions in the preliminary interview form in regards to pseudoscience. 
Figure 4.

Preliminary Interview Findings on Pseudoscience Main Theme

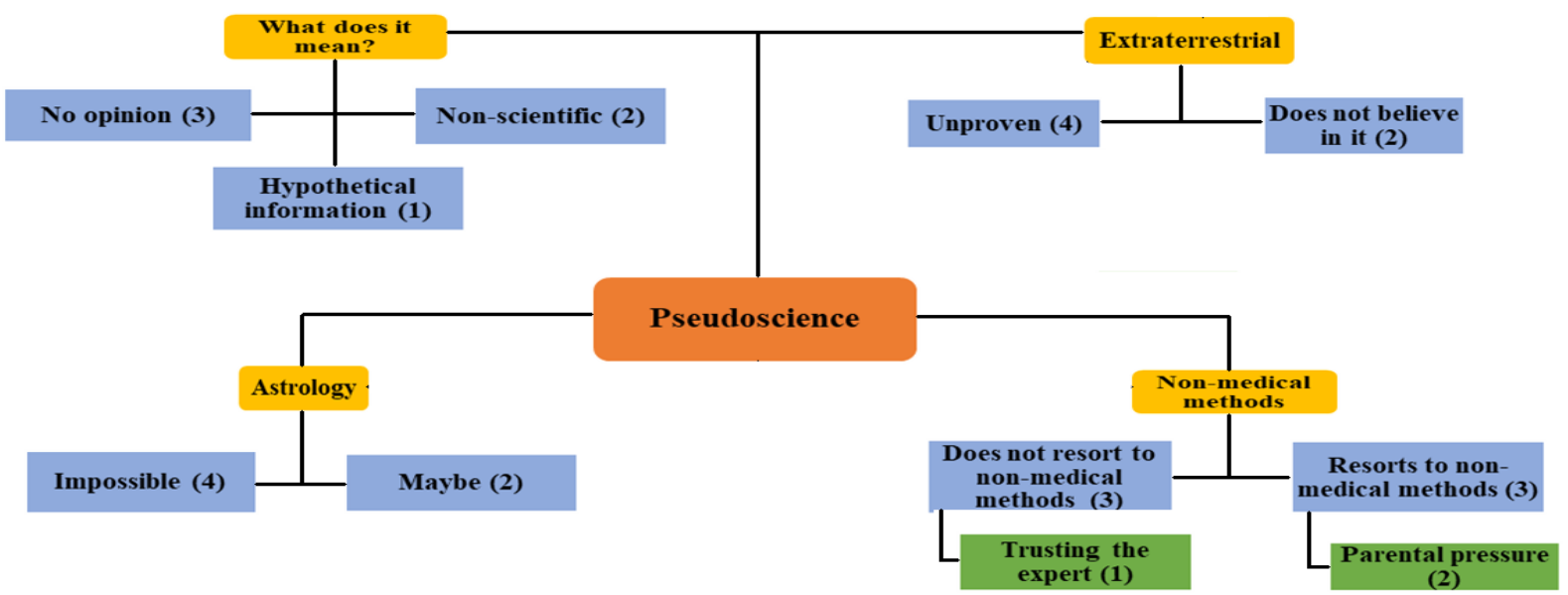

Figure 4 shows that half of the students had no idea about what pseudo-science was. Others described pseudoscience as non-scientific knowledge. That it was not possible to make predictions according to the movement of celestial bodies was mainly reported in the sub-dimension of astrology. Regarding the sub-dimension of extraterrestrial beings, although the majority of the students stated that this has not been proven, there were also students who believed that these beings may exist. One of the participant responses is given below as an example.

P2: “...I do believe it actually. Because there are other planets than our own. They could exist...”

The number of students who resorted to non-medical methods and the number of students who did not use non-medical methods was found to be the same. While those who did not resort to non-medical methods were found to trust experts, parental pressure was found to affect those who apply non-medical methods.

Figure 5.

Final Interview Findings on Pseudoscience Main Theme

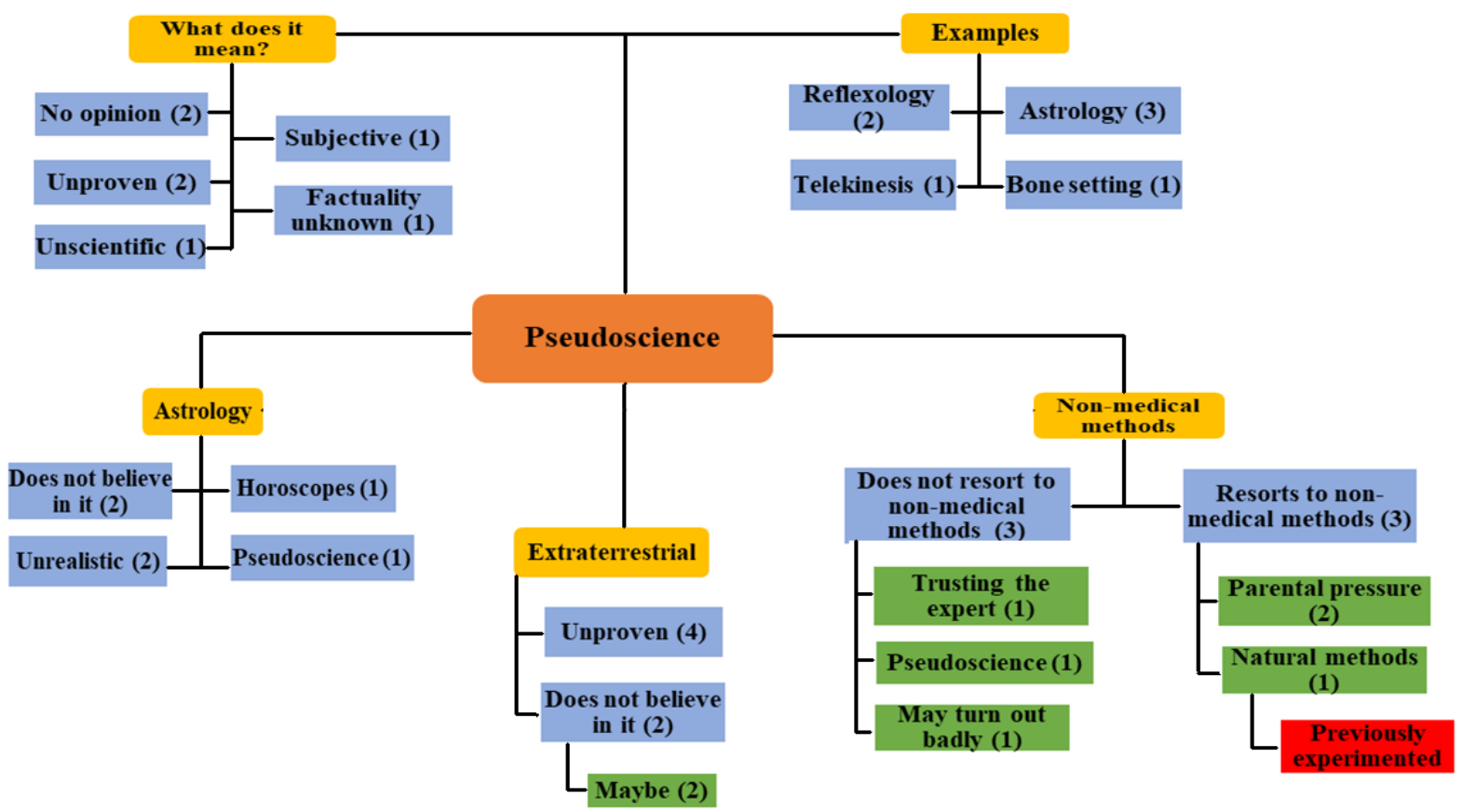


The student responses regarding pseudoscience theme in the final interview form show that some students seemed to have no idea about what pseudoscience meant (see Figure 5). In addition, the codes such as unproven and unscientific were among the responses provided by the students. In addition, it was found that students provided more examples about pseudoscience in the final interview compared to their input in the preliminary interview. Their examples on pseudoscience mostly included astrology and reflexology. While the students could not give any examples of pseudoscience in the preliminary interview, they also cited examples other than astrology and reflexology, the subjects examined in this research, in the final interview. In the sub-theme of astrology, it was found that some of the students did not believe in astrology, while others regarded astrology as an unrealistic and pseudoscientific subject. Excerpts from participants' views on this matter are presented below.

P1: "It's not scientific. It's pseudo-science..."

P6: “...For example, they say make a wish when they see a shooting star. We make the wish and it doesn't come true. I used to believe in it but I don't anymore."

In the sub-theme of extraterrestrials, some students stated that extraterrestrials may exist although the majority of students mentioned that this sub-theme was unproven. Some parts from participant responses are presented below.

P2: "There could be other living beings. There are other planets, but their existence hasn't been proven yet."

P6: "I don't believe they exist. We would have to make observations."

In the sub-theme of applying non-medical methods, it was found that ratio of application and nonapplication of these methods was equal. Among the reasons for not applying non-medical methods were confidence in experts, the possibility of it being pseudoscience and the possibility of getting bad results. Those who stated that they could use these methods reported parental pressure as the reason.

Figure 6.

Preliminary Interview Findings on Superstition Sub-Theme

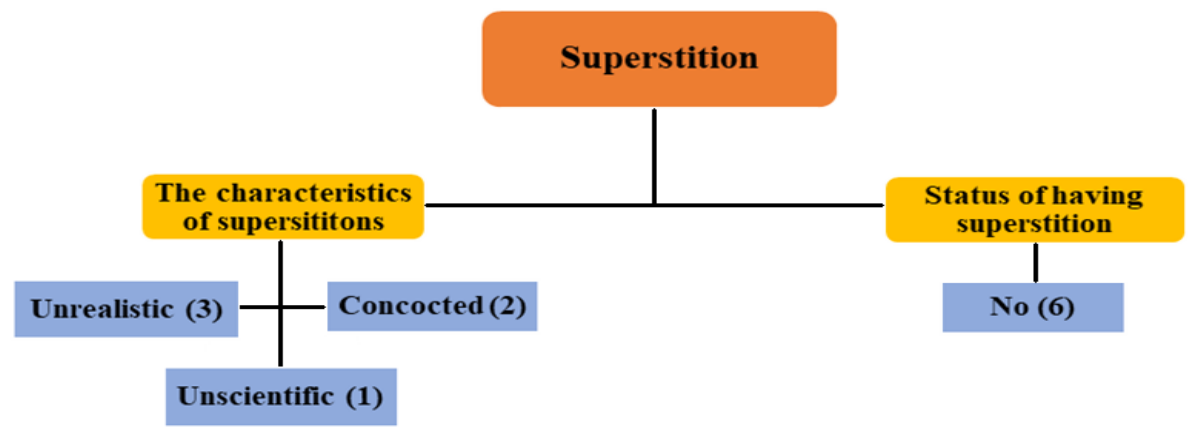

Figure 6 was created based on the answers given to the questions about the subject of superstition in the preliminary interview form. Under the sub-theme of superstition, information about the characteristics of superstitions was obtained along with information about whether students had superstitions. It was found that not all interviewed students had superstitions. The participants defined superstitions as unrealistic, fabricated and unscientific. Quotations from some participant responses are provided below.

P1: "Stuff that doesn't have anything to do with science. That doesn't reflect reality..."

P2: "Untrue. Made up by humans." 
According to the answers given by the students in the last interview form, the status of having superstitious beliefs and characteristics of superstition are represented in Figure 7.

\section{Figure 7.}

Final interview findings on superstition sub-theme

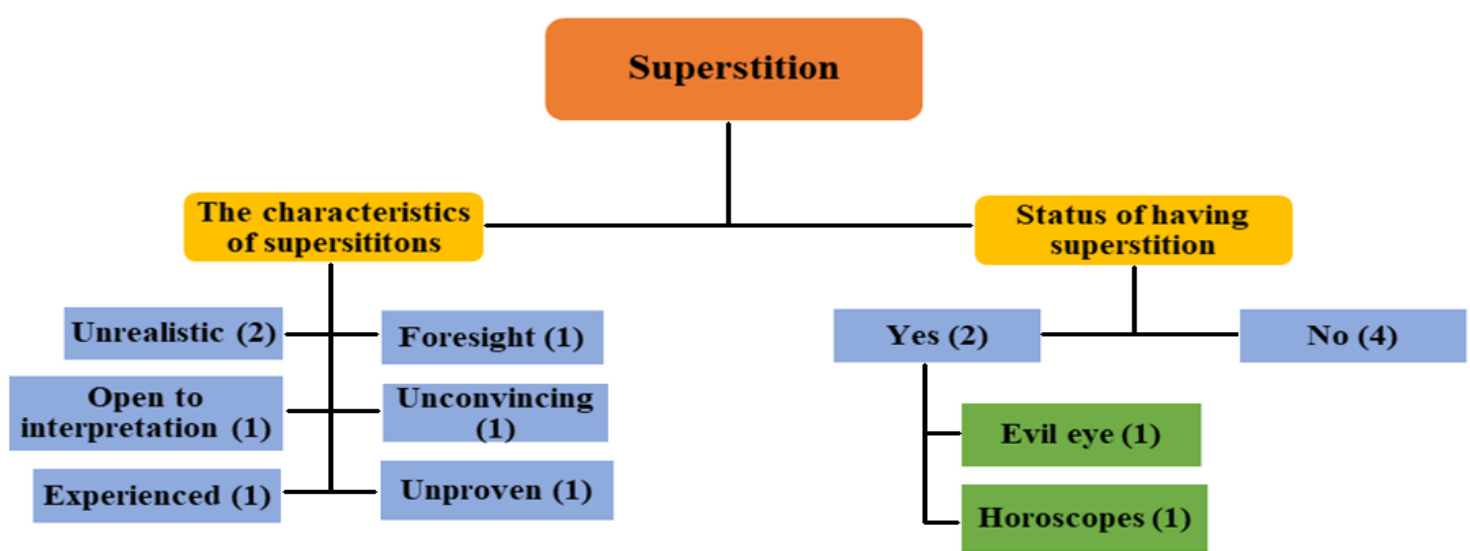

According to Figure 7, while most of the students stated that they did not have superstitions, two female students said that they had superstitions about the 'evil eye' and horoscopes. Considering the features of superstition; codes were generated such as unscientific, unproven, experience and foresight. Examples of participant responses are presented below.

P4: “... I don't believe in this kind of stuff. Some people believe them because some people have such experiences but it doesn't work in every situation."

P2: "Uncertain that it's true, like pseudoscience..."

Both quantitative and qualitative findings show that students improved in regards to the distinction between science and pseudoscience when they were taught with the argumentation approach. It was a desirable result to observe this improvement in students who received low scores and in students who received high scores on the scale. Table 9 presents this improvement on the basis of qualitative findings.

Table 9.

Examples of Interview Showing the Improvement of Students Who Got Low or High Scores in Science -PseudoScience Distinction

\begin{tabular}{|c|c|c|c|}
\hline & Interview Question & Preliminary interview & Final interview \\
\hline \multirow{2}{*}{$\begin{array}{l}\text { Sections from } \\
\text { student } \\
\text { interviews } \\
\text { /low scale } \\
\text { scores }\end{array}$} & $\begin{array}{l}\text { What do you think about } \\
\text { predicting the future with the } \\
\text { movements of celestial } \\
\text { bodies? }\end{array}$ & $\begin{array}{l}\text { P1: "I would say it is } \\
\text { impossible. I would say } \\
\text { no." }\end{array}$ & $\begin{array}{l}\mathrm{P} 1: \text { "It is not scientific. It is in } \\
\text { the realm of pseudoscience." }\end{array}$ \\
\hline & $\begin{array}{l}\text { What do you understand } \\
\text { from the term "scientific } \\
\text { knowledge"? }\end{array}$ & $\begin{array}{l}\text { P3: "Knowledge that has } \\
\text { been proven, } \\
\text { experimented upon, } \\
\text { reached a conclusion." }\end{array}$ & $\begin{array}{l}\text { P3:... "Research, observation } \\
\text { but mostly based on observation } \\
\text { because some things may not be } \\
\text { obtained by doing experiments." }\end{array}$ \\
\hline \multirow{2}{*}{$\begin{array}{l}\text { Sections from } \\
\text { student } \\
\text { interviews } \\
\text { /high scale } \\
\text { scores }\end{array}$} & $\begin{array}{l}\text { In your opinion, what are the } \\
\text { characteristics of scientific } \\
\text { knowledge? }\end{array}$ & P4: “I don't know.” & $\begin{array}{l}\mathrm{P} 4: . . . \text { "It has to be obtained as a } \\
\text { result of research, observation } \\
\text { and experiment." }\end{array}$ \\
\hline & $\begin{array}{l}\text { In your opinion, what are the } \\
\text { characteristics of scientific } \\
\text { knowledge? }\end{array}$ & $\begin{array}{l}\text { P6: "It should be based } \\
\text { on research." }\end{array}$ & $\begin{array}{l}\text { P6:... "Scientific knowledge } \\
\text { may change. Scientific } \\
\text { knowledge is based on } \\
\text { experimentation and } \\
\text { observation. It is shaped } \\
\text { according to research." }\end{array}$ \\
\hline
\end{tabular}


Based on the examination of student views in Table 9, it can be argued that students who received low or high scores from the scale improved in regards to the distinction between science-pseudoscience in the quantitative dimension of the study. When the obtained results were evaluated in general, it was found that both common and different findings emerged from the quantitative and qualitative dimensions of the study. When the quantitative findings of the research were analyzed, it was observed that post-instruction mean scores were lower than the pre-instruction mean scores for both the overall scale and for all sub-dimensions. In addition, it was found that the average of 11 items in the scale implemented pre-instruction were over 3 points, while only 1 item in the scale was over 3 points postinstruction. These results may be indicative of an improvement in distinguishing between science and pseudoscience. Similarly, qualitative findings demonstrate that student ideas about both scientific knowledge and pseudoscience were found to change and develop. Therefore, it can be concluded that quantitative and qualitative findings in this study supported each other. However, while quantitative findings in themselves showed that the results supported the development of science-pseudoscience distinction, an unexpected situation emerged in the superstition sub-dimension of qualitative findings. While the 6 students interviewed were found to have no superstitions in the preliminary interviews, 2 female students reported having superstitions during the last interview. In addition, it was found that these students had low pre-test scores o and their pseudoscientific beliefs were below average. At this point, it can be argued that there were no parallels between the quantitative and qualitative findings of the study. The emergence of superstitions in the last interviews may also suggest that awareness was created for these students with the information obtained during the instruction process. In addition, the adequacy of the instruction provided by the argumentation method can be a topic of discussion as well.

\section{DISCUSSION AND CONCLUSION}

This study aimed to determine eighth grade students' opinions about the science-pseudoscience distinction and to develop these views with the argumentation method. In this context, the following conclusions were drawn.

Based on the analyzes undertaken for the first dimension of the study, no significant difference was found in the pseudoscientific beliefs based on gender in terms of the scores obtained from the pseudoscientific belief scale before and after the implementation. Some other studies in the literature also reported that pseudoscientific beliefs are not gender dependent (Berkant \& Ermeydan, 2017; Gül, 2016; Lundström, 2007; Şahin \& Uçar, 2018). It can be argued that studies relevant to the present research show consistent results. However, it may not be correct to conclude that the pseudoscientific beliefs are completely independent of the gender factor. As a matter of fact, a difference was observed in the post-test results based on the gender factor for the pseudo-physical sub-dimension (see Table 4). Also, literature has some findings that pseudoscientific beliefs depend on the gender factor (Losh \& Nzekwe, 2011; Williams et al., 2007). For example, Losh and Nzekwe's (2011) study concluded that women believe in astrology more. The finding that two female students had pseudoscientific beliefs in the superstition sub-theme in the qualitative findings of the study is consistent with both quantitative findings and international literature. It is believed that lifestyle, social environment, education and social media can be effective in this result. Analysis of the scale scores after the argumentation-based instruction shows that the average scores of male students were lower, although not statistically significant. This situation may partly indicate that pseudoscientific beliefs are lower in male students.

In a parallel manner, the results of the studies conducted by Williams et al. (2007) with high school students, by Gül (2016, p. 183) with teacher candidates and by Berkant and Ermeydan (2017) with students, showed that males were more successful than girls in distinguishing science from pseudoscience. The results obtained in this study is believed to originate from differences in interests, genders and the context (astrology, reflexology, ufology, etc.) as well as the type of information that the students were exposed. 
The analyses undertaken for the second dimension of the study showed a significant difference between the scores of pseudoscience belief scale implemented pre and post instruction. This finding is consistent for all sub-dimensions. According to the data obtained from the qualitative dimension, it can be argued that there was an increase in student opinions and information regarding the characteristics of scientific knowledge in the last interviews compared to pre-interviews. It is also concluded that there was a change and development in distinguishing between scientific and non-scientific knowledge. Similarly, while students' pseudoscience perceptions were very superficial in the preliminary interview, they were able to provide more ideas and examples about the pseudoscience - in the last interview. In other words, it can be concluded that the argumentation method applied in this study positively affected the process. When student perceptions about science-pseudoscience distinction at the beginning of studies conducted by Turgut et al. (2016), were examined, it was concluded that the participants had superficial information on scientific knowledge. In addition, researchers also stated that students have poor reasoning skills in distinguishing between science and pseudoscience. Taking these results in the literature into consideration, it can be argued that the findings of the present study are in line with the conclusions of relevant studies. When the findings of the study are evaluated within this study, it can be argued that quantitative and qualitative data supported each other. For example, based on both the pre-instruction scale results and findings obtained from pre-interviews, it was concluded that students' knowledge about pseudoscience was quite superficial and they were unable to make a distinction between science and pseudoscience. However, it is possible to talk about a positive change in general in both the results of the scale and post-instruction interview findings. The significant difference found between the scores obtained from the pseudoscience belief scale applied before and after the instruction can be considered as the effect of the four-week argumentation-oriented process. The inquiries made by the students in this scientific discussion environment may have contributed to the change that occurred in this process. In addition, it can be stated that students' efforts to present scientific bases while defending their views were effective in distinguishing the non-scientific parts in the texts used in this study. The positive change in the scale results may indicate that the criteria obtained in the argumentation process are also used in assessing different types of information.

These results are in line with the argumentation-oriented pseudoscience study conducted by Arik (2016). In addition, Çetinkaya et al. (2015) carried out a teaching process in order to develop the pseudosciencescience distinction with the eighth grade students by using classroom discussions. Positive results were obtained in this study. The finding that the participants increased their knowledge about the distinction between science- pseudoscience through argumentation approach was supported by the studies conducted by Çekbas (2017) with science teacher candidates and Eş and Turgut (2018) with classroom teacher candidates.

In addition, examination of the item averages of the scale used in the study showed that 11 items in total were above average, that is, the pseudoscience perception was high. It was concluded that these items mostly belonged to the pseudo-physical and pseudo-medical sub-dimensions of the scale. The fact that only one item was found to be above average when the item averages of the scale were analyzed for post-instruction phase may be another indication that the process was successful. When the results in the pseudoscience belief scale were examined on the basis of individuals, it was found that 14 out of 32 students remained above the average scale score compared to pre-instruction results. In other words, it can be argued that these students had high pseudoscientific beliefs. The qualitative dimension of the study was found to support the quantitative results. It was observed in the preliminary interview that half of the students had no idea about pseudoscience and approximately a quarter of the students believed in the sub-dimensions of pseudoscience. In addition, it was observed that the students did not provide satisfactory answers in the preliminary interviews about the science-pseudoscience distinction. In addition, studies conducted by Turgut (2009), Ayvacı and Bağ (2016), Şahin and Uçar (2018) concluded that the participants were incompetent in distinguishing between science and pseudoscience. The fact that the number of students who remained above the average scale score decreased from 14 to 8 according to the results of the pseudoscience belief scale post-instruction may indicate that the process was effective. In their study conducted with 8th grade secondary school students on the iridology case, Çetinkaya et al. (2015) also stated that positive results could be obtained and students could develop the 
ability to distinguish between science and pseudoscience when the appropriate teaching environment was created. Considering the fact that students in this study also demonstrated improvement, it can be argued that similar results were obtained here as well. Having the same age group as participants in both studies may be effective in obtaining similar results.

The third dimension of the research, the preliminary opinions of students on scientific knowledge, showed that the students regarded scientific information as the experimental and proven information obtained as a result of the research in general. The fact that both university and secondary school students defined scientific knowledge as "proven, includes experiment-observation and proposed by experts" supports the results achieved in this study (Saka \& Sürmeli, 2017; Tatar et al., 2011; Turgut et al., 2016). In addition, the fact that students regarded pseudoscience as unproven information during the qualitative aspect of the study revealed the viewpoint that science should be proven. Tatar et al. (2011) found that teacher candidates emphasized the concepts of proof while distinguishing scientific and non-scientific information. During the preliminary and final interviews, when students voiced their opinions on scientific knowledge and what science meant, it was observed that students talked less about experimentality and mentioned the concept of observation more. In this context, focusing more on observation in science can be considered as an acquisition. Similarly, teacher views on the necessity of experiments in science were found to change at the end of the implementation process conducted with teacher candidates (Ağlarcı \& Kabapınar, 2016). This result is thought to support the study findings. According to the results of the preliminary and final interviews with the students, it was observed that there was no change in terms of how information was accessed. It is thought that more emphasis should be placed on this part during the teaching process.

The fourth dimension of the research examined student opinions on pseudoscience. It is believed that it would be more appropriate to compare students' pre and post argumentation-based views. It can be argued that science-pseudoscience distinction in students and their scientific perceptions develop in some categories (features of pseudoscience, superstition, etc.) in the process. However, while two students stated that they had no superstitious beliefs before the implementation, the same students expressed the existence of superstitious beliefs in the interview after the implementation. At this point, the absence of superstitious beliefs in the pre-interviews should not be considered as a good result because those students were not aware of superstitious beliefs before teaching and regarded related information as scientific. In other words, since students were not aware of the problematic situation, they were unable to express their ideas and superstition may have appeared to be absent in the preliminary interviews. In the last interviews, those two students stated that although the evil eye and horoscopes were superstitious, they were still interested in these issues. At this point, it can be argued that the teaching performed could not completely eliminate the pseudoscience perception or it was simply inadequate. Another interesting finding emerged in the axis of this result. When the data obtained from the data collection tools were examined in a comparative manner, it was found that one of the two female students with a low score of the pseudoscience belief scale stated before instruction that she believed in the zodiac and the other one stated she believed in the 'evil eye'. It is noteworthy that another female student with a high pseudoscience belief scale score during the pre-instruction phase did not have any superstitions. In addition, it was observed that students who scored low on the pseudoscience belief scale had beliefs in the pseudoscience sub-dimensions such as astrology, extraterrestrial beings and nonmedical methods. It can be concluded that high or low scores from the pseudoscience belief scale is not a determining factor in the beliefs related to pseudoscience sub-dimensions. There are also results in the literature supporting this research (Afonso \& Gilbert, 2010; Kallery, 2001; Lundström, 2007). In these studies, the pseudoscientific tendencies of teacher candidates were thought to be independent from variables such as education level and having received science education. Again, the literature suggests that teacher candidates' pseudoscientific beliefs such as talismans, horoscopes and dream interpretation, despite their rather high knowledge level about the distinction between science and pseudoscience, supports the results obtained in this study (Şahin \& Uçar, 2018; Şenler \& İrven, 2016). In the study conducted by Sugarman et al. (2011), scientific knowledge and scientific attitudes of 10000 university students were investigated. The study determined that a strong relationship did not exist between science literacy and understanding that astrology is pseudoscience. The data obtained as a result of this study 
were shaped based on the scale, teaching method and the pseudoscientific texts chosen during the teaching process. It is thought that using different scales, methods and pseudoscientific texts can change the results obtained here.

\section{Recommendations}

The existence of substantial pseudoscientific beliefs in students should be seen as an issue that needs attention in the education system and solutions should be sought. In this context, it may be suggested to include some chapters in the science curriculum where the distinction between science and pseudoscience can be addressed with comparative examples through interesting contexts. Further research can be done in the future by conducting this study with study groups from different regional and classroom levels. In addition, researchers who want to work on this subject are advised to design other themes and contexts by changing the texts used in the implementation process in this study. A partial improvement in the students' views on scientific knowledge in the context of distinguishing science from pseudoscience was observed in a four-week practice in the framework of this study. It may be possible to achieve a higher level of development in scientific knowledge with lengthier or different teaching methods.

\section{REFERENCES}

Afonso, A. S. \& Gilbert, J. K. (2010). Pseudo-science: A meaningful context for assessing nature of science. International Journal of Science Education, 32(3), 329-348. https://doi.org/10.1080/09500690903055758

Ağlarcı, O. \& Kabapınar, F. (2016). Sınıf öğretmen adaylarının bilime ve sözde bilime ilişkin görüşlerinin geliştirilmesi [Developing prospective chemistry teachers' views of science and pseudoscience]. Amasya Education Journal, 5(1), 248-286. https://doi.org/10.17539/aej.33301

Arık, M. (2016). Argümantasyon tabanlı ögrenme yönteminin yedinci sinıf ögrrencilerinin bilim sözde-bilim ayrım farkındalı̆̆ının geliștirilmesi üzerine etkisi [Effectiveness of argumentation-based learning on seventh grade students' awareness about demarcation of science]. (Unpublished master's thesis). Istanbul University.

Arık, M. \& Akçay, B. (2018). Argümantasyonun öğrencilerin bilimin sözde-bilimden ayırma becerilerinin geliştirilmesi üzerine etkisi [An effectiveness on engaging in argumentation on students' ability to demarcate science from pseudoscience]. Sakarya University Journal of Education, 8(1), 41-60. https://doi.org/10.19126/suje.338919

Ayvacı, H. Ş. \& Bağ, H. (2016). Sınıf öğretmeni adaylarının bilim sözde-bilim ayrımına ilişkin görüşlerinin incelenmesi [Investigating the views of primary school teacher candidates' for science pseudo-science distinction]. Amasya Education Journal, 5(2), 539-566. https://doi.org/10.17539/aej.62204

Berkant, H. G. \& Ermeydan, Z. (2017). Eğitim fakültesi öğrencilerinin bilim-sözde bilim ayrımlarının çeşitli değişkenler açısından incelenmesi [An investigation of faculty of education students' distinctions between science and pseudoscience in terms of various variables]. Kahramanmaras Sutcu Imam University Journal of Education, 1(1), 12-25.

Bunge, M. (2011). Knowledge: Genuine and bogus. Science \& Education, 20(5-6), 411-438. https://doi.org/10.1007/s11191-009-9225-3

Creswell, J. W. (2017). Research design. Sage Publications.

Creswell, J. W. \& Plano Clark, V. L. (2018). Designing and conducting mixed method research. Sage Publications.

Çekbaş, Y. (2017). Argümantasyon tabanll astronomi öğretiminin fen bilgisi öğretmen adaylarının bilimin doğasina, sözde-bilim ve epistemolojik inançlarına etkisinin değerlendirilmesi [The evaluation of the effect of an astronomy course based on argumentation on pre-service science teachers' nature of science, pseudoscience and epistemological beliefs]. (Unpublished doctoral dissertation). Pamukkale University.

Çetinkaya, E. \& Taşar, M. F. (2018). Sözde-Bilim inanış ölçeğinin (SïÖ) geliştirilmesi: Geçerlik ve güvenirlik çalışması [Development of pseudoscience belief scale (PBS): Validity and reliability study]. Trakya Journal of Education, 8(3), 497-512. https://doi.org/10.24315/trkefd.336650

Çetinkaya, E., Turgut, H. \& Duru, M. K. (2015). Bilim, sözde-bilim ayrımı bağlamının ortaokul öğrencilerinin bilim algilarına etkisi: İridoloji vakas1 [The effect of the context of science, pseudoscience demarcation on the science perceptions of secondary school students: The case of Iridology]. Education and Science, 40(181), 1-18. https://doi.org/10.15390/EB.2015.3127 
DeVellis, R. F. (2003). Scale development: Theory and applications. Sage Publications.

Efthimiou, C. J. \& Liewellyn, R. A. (2006). Is pseudoscience the solution to science literacy?. http://arxiv.org/pdf/physics/0608061v1.pdf

Einstein, A. (1940). Considerations Concerning the Fundamentals of Theoretical Physics. Science, 91(2369), 487492.

Eş, H. \& Turgut, H. (2018). Candidate classroom teachers ${ }^{e e}$ perceptions about being scientific in the context of pseudoscience. Journal of Education in Science, Environment and Health (JESEH), 4(2), 142-154. https://doi.org/10.21891/jeseh.409497

Guba, E. G. \& Lincoln, Y. S. (1982). Epistemological and methodological bases of naturalistic inquiry. Educational Communication and Technology Journal, 30(4), 233-252.

Gül, S. (2016). Biyoloji, fizik ve kimya öğretmen adaylarının bilim-sözde bilim ayrımı anlayışları [Prospective Biology, physics and chemistry teachers' conceptions towards science-pseudoscience distinction]. Journal of Theoretical Educational Science, 9(2), 177-197. https://doi.org/10.5578/keg.10871

Impey, C., Buxner, S. \& Antonellis, J. (2012). Non-scientific beliefs among undergraduate students. Astronomy Education Review, 11(1), 101-111. https://doi.org/10.3847/AER2012016

Johnson, M. \& Pigliucci, M. (2004). Is knowledge of science associated with higher skepticism of pseudoscientific claims? The American Biology Teacher, 66(8), 536-548. https://doi.org/10.2307/4451737

Kallery, M. (2001). Early-Years educators' attitudes to science and pseudo-science: The case of astronomy and astrology. European Journal of Teacher Education, 24(3), 329-342. https://doi.org/10.1080/02619760220128888

Kaplan, A. O. (2014). Research on the pseudo-scientific beliefs of pre-service science teachers: A sample from astronomy-astrology. Journal of Baltic Science Education, 13(3), 381-393.

Kaya, M. \& Bacanak, A. (2013). Fen ve teknoloji öğretmen adaylarının düşünceleri: Fen okuryazarı birey yetiştirmede öğretmenin yeri [Science and technology teacher candidates' views: The role of teachers to educate individuals as scientific literate]. Dicle University Journal of Ziya Gökalp Faculty of Education, 21, 209-228.

Kaya, O. N. \& Kılıç, Z. (2008). Etkin bir fen öğretimi için tartışmacı söylev [Argumentative discourse for the effective teaching of science]. Ahi Evran University Journal of Kırşehir Education Faculty, 9(3), 89-100.

Kirman Çetinkaya, E., Laçin Şimşek, C. \& Çalışkan, H. (2013). Bilim ve sözde-bilim ayrımı için bir ölçek uyarlama çalışması [The Adaptation study of science and pseudoscience distinction]. Trakya Journal of Education, 3(2), 31-43.

Kuhn, T. S. (1996). The structure of scientific revolutions. The University of Chicago Press.

Lakatos, I. (2014). The methodology of scientific research programmes. Cambridge University Press.

Lambert, K. \& Brittan, G. G. (2011). An introduction to the philosophy of science. Ridgeview Publishing.

Liu, X. (2009). Beyond science literacy: Science and the public. International Journal of Environmental \& Science Education, 4(3), 301-311.

Losh, S. C. \& Nzekwe, B. (2011). Creatures in the classroom: Preservice teacher beliefs about fantastic beasts, magic, extraterrestrials, evolution and creationism. Science \& Education, 20(6), 473-489. https://doi.org/10.1007/s11191-010-9268-5

Lundström, M. (2007). Students' beliefs in pseudoscience. http://muep.mau.se/handle/2043/4701.

Martin, M. (1994). Pseudoscience, the paranormal, and science education. Science \& Education, 3(4), $357-371$. https://doi.org/10.1007/BF00488452

McComas, W. F (1998). The principal elements of the nature of science: Dispelling the myths. In W. F. McComas (Ed.), The nature of science in science education: Rationales and strategies. (53-70). Kluwer.

McLean, C. P. \& Miller, N. A. (2010). Changes in critical thinking skills following a course on science and pseudoscience: A quasi-experimental study. Teaching of Psychology, 37(2), 85-90. https://doi.org/10.1080/00986281003626714.

Metin, D. (2015). Middle school students' reasoning patterns and comprehensions about pseudoscientific applications related to crystals. [Unpublished doctoral dissertation]. Middle East Technical University, AnkaraMinistry of National Education (MoNE) (2005). Elementary and secondary science curriculum. National Education Press.

Miles, M. B. \& Huberman, A. M. (1994). An expanded sourcebook: Qualitative data analysis. Sage Publications Ltd.

Norris, S. P. \& Phillips, L. M. (2003). How literacy in 1ts fundamental sense is central to scientific literacy. Science Education, 87(2), 224-240. DOI: 10.1002/sce.10066

Osborne, J., Erduran, S. \& Simon, S. (2004). Enhancing the quality of argumentation in school science. Journal of Research in Science Teaching, 41(10), 994-1020. https://doi.org/10.1002/tea.20035

Popper, K. (2002). The logic of scientific discovery. Routledge Publishing.

Russell, B. (1997). Religion and science. Oxford University Press. 
Saka, M. \& Sürmeli, H. (2017). Fen bilgisi öğretmen adaylarının sözde bilimsel senaryolarda bilimin doğasını kullanımı [Preservice Science teachers' use of NOS in pseudoscientific scenarios]. Trakya Journal of Education, 7(2), 504-525. https://doi.org/10.24315/trkefd.305999

Shein, P. P., Li, Y. Y. \& Huang, T. C. (2014). Relationship between scientific knowledge and fortune-telling. Public Understanding of Science, 23(7), 780-796. https://doi.org/10.1177/0963662514522169

Soslu, O. (2014). Fen eğitiminde bilimin doğasını anlama üzerine bir değerlendirme [An evalation about understanding the nature of science in science education]. Bayburt University Faculty of Education, 9(1), 90-100Sönmez, V. (2008). Bilim felsefesi [Philosophy of science]. An1.

Sugarman, H., Impey, C., Buxner, S. \& Antonellis, J. (2011). Astrology beliefs among undergraduate students. Astronomy Education Review, 10(1), 10-21. https://doi.org/10.3847/AER2010040

Şahin, E. \& Uçar, M. B. (2018). Pre-service science teachers' discrimination level of science and pseudoscience. Science Education International, 29(4), 267-273.

Şahin, T. E. (2006). Bilim, bilimler ve bilgi alanları [Science, sciences and fields of knowledge]. Dikey Publishing.

Şenler, B. \& İrven, Ö. (2016). Sınıf öğretmeni adaylarının epistemolojik inançları ile sözde-bilimsel inançları [Primary pre-service teachers' epistemological beliefs and pseudoscientific beliefs]. Mersin University Journal of the Faculty of Education, 12(2), 659-671. https://doi.org/10.17860/efd.25364

Tatar, E., Karakuyu, Y. \& Tüysüz, C. (2011). Sınıf öğretmeni adaylarının bilimin doğası kavramları: teori, yasa ve hipotez [Prospective primary school teachers' concepts of the nature of science: theory, law and hypothesis]. Mustafa Kemal University Journal of Social Sciences Institute, 8(15), 363-370.

Topdemir, H. G. (2002). Kuhn ve bilimsel devrimlerin yapısı üzerine bir değerlendirme [An assessment of Kuhn and the nature of scientific revolutions]. World of Philosophy, 36(2), 45-62.

Tsai, C. Y., Lin, C. Y., Shih, W. L. \& Wu, P. L. (2015). The effect of online argumentation upon students' pseudoscientific beliefs. Computers \& Education, 80, 187-197.

Tseng, Y. C., Tsai, C. Y., Hsieh, P. Y., Hung, J. F. \& Huang, T. C. (2014). The relationship between exposure to pseudoscientific television programmes and pseudoscientific beliefs among Taiwanese University students. International Journal of Science Education, Part B, 4(2), 107-122.

Turgut, H. (2009). Fen ve teknoloji öğretmen adaylarının bilimsel sözde-bilimsel ayrımına yönelik algıları [Preservice science teachers' perceptions about demarcation of science from pseudoscience]. Education and Science, 30(154), 50-68.

Turgut, H., Akçay, H. \& İrez, S. (2010). Bilim sözde-bilim ayrımı tartışmasının öğretmen adaylarının bilimin doğası inanışlarına etkisi [The impact of the issue of demarcation on pre-service teachers' beliefs on the nature of science]. Educational Sciences: Theory and Practice, 10(4), 2621-2663. https://doi.org/10.1007/s11191-010-9250-2

Turgut, H., Eş, H., Bozkurt Altan, E. \& Öztürk Geren, N. (2016). Pre-service pre-school teachers' perceptions of science and pseudoscience. International Online Journal of Educational Sciences, 8(1), 150-169. https://doi.org/10.15345/iojes.2016.01.013

Tutar, H. (2014). Bilim ve sözdebilim [Science and pseudoscience]. Seçkin.

Williams, E., Francis, L. \& Robbins, M. (2007). Personality and paranormal belief: a study among adolescents. Pastoral Psychology, 56(1), 9-14. https://doi.org/10.1007/s11089-007-0094-X

Yıldırım, A., \& Şimşek, H. (2016). Sosyal bilimlerde nitel araştırmalar [Qualitative researches in social sciences]. Seçkin.

Yildırım, C. (2010). Bilim felsefesi [Philosophy of science]. Remzi. 


\section{APPENDICES}

\section{Appendix A: Interview Form}

1. What do you understand when you hear the term "scientific knowledge"?

2. In your opinion, what are the characteristics of scientific knowledge?

3. How can we distinguish between scientific and non-scientific knowledge? How can we access scientific knowledge?

4. What do you understand when you hear the term "pseudo-science"? Can you give an example?

5. What do you understand when you hear the term "superstition"? In your opinion, what can be the characteristics of superstitions?

6. Do you have superstitions? If your answer is yes, please cite them.

7. What do you think about predicting the future based on the movements of the celestial bodies?

8. Do you resort to non-medical methods when you get sick? Why?

9. What are your views on the existence of extraterrestrial beings? 


\section{Appendix B: Pseudoscience texts}

\section{1- Astronomy-Astrology}

\section{Example for Astrology: A Bonus to Those Who Keep Their Energy High}

The Solar Eclipse, which will take place on the morning of April 29 at 9.14 in Taurus at 8 degrees, provides bonuses to those who keep their energy high. This eclipse, which will be effective until the solar eclipse on 23 October 2014, will mostly affect the earth groups followed by the water groups. In addition, people whose rising sings are earth or water, or those whose earth or water nature is high on the planet map will also have very positive effects. Since the characteristic of Taurus is productivity, land, property, property, money and luck, almost every member of this zodiac sign will encounter beautiful surprises related to these issues. Some will be buying houses, some will have a lot of money, or long-term and fruitful relationships will begin. Many will have long-lasting and solid jobs and marriages. It seems that the foundations of marriages or business initiatives that take place after the eclipse will be solid (https://www.internethaber.com/gokyuzu-yarin-sabah-bonus-dagitacaknbsp665692h.htm)

\section{Example for Astronomy: Solar Eclipse}

It is the natural phenomenon observed when the Moon enters between the Earth and the Sun during its orbital movement and therefore partially or completely covers the Sun. In order for the eclipse to occur, the Moon must be in the lunar phase, and in conjunction with the Sun in comparison to Earth, that is, the orbital plane must coincide with the orbital plane of the Earth around the Sun. Although the Moon rotates about 12 times around the Earth within a year, the Moon does not pass directly in front of the Sun each time, as a result of an angle of about 5 degrees between the orbital plane of the Earth and the orbital plane of the Moon, and this overlap occurs infrequently. Therefore, between two and five solar eclipses are observed annually. Two of them can be full eclipse. Eclipse follows a narrow corridor on Earth. Therefore, solar eclipse is a very rare event for any region.

\section{2- Reflexology}

Figure B1.

Hand Reflexology - Certain Points

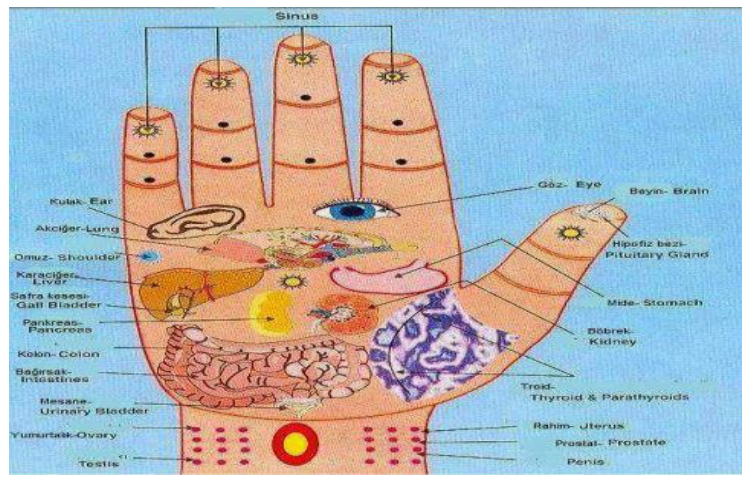

In the simplest form, reflexology argues that diseases can be treated by applying massage or different techniques to some points on the hands and feet. Reflexology maintains that stimulating nerve points with certain techniques produces electrochemical messages that stimulate the relevant organs with the help of neurons. Foot and hand reflexology is the stimulation of nerves and blood circulation in the body by manually stimulating certain points (See Figure B1). The most common application is foot reflexology. In the past, Inca and Chinese civilizations used this method for all neurological diseases, including migraine, cervical disc hernia and slipped discs, thyroid and stomach disorders. In addition, 
reflexology therapy is known to relieve the individual from daily stress and anxiety. There are five basic pressure-point techniques for the massage of reflex zones: thumb-walking, finger walking, pivoting, sliding and pinching. These are applied to both hands and feet in the same way. The important thing is how to apply this technique to whom. The physical build, age and current health status of the person are taken into consideration. For example, while pressure points are applied more strongly to a strong person during massages, weaker persons, elderly and children are massaged by using the pressure points more mildly. Treatment consists of applying pressure with the edge of the thumb or another finger and rotating it clockwise. This pressure is usually quite deep, but it doesn't have to be painful. Each session lasts from 10 minutes to 30 minutes, and several sessions may be needed (https://www.refleksoloji.org/refleksoloji-nedir/). 


\section{Appendix C: Sample teaching plan}

Sample teaching plan is shown in Table C1 and Table C2.

Table C1.

Sample Teaching Plan Part I

\begin{tabular}{ll}
\hline Name of the Lesson: & Science Applications \\
\hline Grade: & 8 \\
\hline Subject: & Reflexology \\
\hline Duration: & $40+40$ minutes \\
\hline $\begin{array}{l}\text { Teaching methods and } \\
\text { techniques: }\end{array}$ & $\begin{array}{l}\text { Teaching by presentation, teaching by discovery, Q\&A and argumentation } \\
\text { method }\end{array}$ \\
\hline
\end{tabular}

Table C2.

Sample Teaching Plan Part II

Engage The teacher (one of the researchers) enters the classroom and greets the students and asks about their day. Then ask the following question to get students' attention: "Who do we consult and where do we go when we are sick or fell ill? Which methods and techniques do we prefer to overcome such negative situations?" After eliciting responses, the teacher continues: "In this lesson we will learn about a method that people use to get rid of their illnesses or ailments, a method that perhaps some of you are familiar with."
Explore The questions asked by the teacher in the introduction are answered by the students in this part. The teacher only guides the students without evaluating their answers. The teacher tries to reveal the students' prior knowledge on this subject by asking new questions based on students' responses. At this stage, the teacher ensures that majority of the class is active.

Explain After hearing students' responses, the teacher adds the following: "the method we will learn today is called reflexology" and presents the relevant text on the subject on the smart board. If students have questions about the text, they are answered by the teacher.

Eloborate At this stage, groups are formed from students sitting near each other. An argumentation form is distributed to each group. Students are requested to fill this form by examining the reflexology text and engaging in group discussions. It is ensured that the scientific or non-scientific information in the text is identified first and the form is filled in by expressing the reasons for this distinction. The entire class is included in the argumentation process. The teacher walks around the groups so that students do not deviate from the purpose of the group discussions and support can be provided to eliminate the difficulties encountered in filling out the forms. At this stage of the lesson, the teacher acts as a guide and administrator. After the forms are filled with in-group discussions, classroom discussions begin. Groups present the scientific or non-scientific information they have identified in the text with their justifications. The teacher starts a classroom discussion in line with the student responses. In this process, students are encouraged to use the arguments they write on the forms while justifying their thoughts.

Evaluate In this part, the scientific or non-scientific information in the reflexology text, identified by the groups and revised and shaped based on the discussions, is written on the board with their justifications. At this stage, the teacher and students participate in the evaluation process. Students express their opinions in regards to incoming questions and objections. If there are errors in the classification, the teacher makes the necessary explanations and ends the lesson by correcting the mistakes. The teacher thanks the students for their participation. 


\section{TÜRKÇE GENIŞLETILMIŞ ÖZET}

Bilimin üzerinde uzlaşılmış net bir tanım bulunmamaktadır. Yapılan birçok tanımlamaya rağmen halen hangi açıklamaların bilimsel olarak kabul edilmesi gerektiği ile ilgili net bir sonuç ortaya çıkarılamamıştır (Lambert \& Brittan, 2011). Bu nedenle bilimsel olan ve bilimsel olmayan bilginin ayrımında da zorlanılmaktadır. Bir düşünce veya araştırmaya bilimselmiş gibi yaklaşılması insanların dikkatini o konuya çekmekte ve değer vermesine yol açabilmektedir. Bilimin çok değer görmesi bilim adı altında sözde-bilimsel alanları ya da inanışları da ortaya çıkarmıştır. Bu bağlamda sözde-bilim, bilimsel gibi görünen belirli bir mantığa göre düzenlenmiş önermeler, uygulamalar ve tutumların tamamı olarak tanımlanabilir (Martin, 1994). Öte yandan bilimsel normlara sahipmiş izlenimi veren sözde-bilim, bilimin süreç ve terminolojisini kopya eden, yeni bilimsel bilgiler kapsamında yenilenemeyen ve bilimsel araştırmalara katkıda bulunamayan dayanaksız düşünceler bütünü olarak görülmektedir (Tutar, 2014, s. 278). Günümüzde astroloji, numeroloji, grafoloji, refleksoloji, UFO, şifalı taşlar, homeopati, reenkarnasyon, parapsikoloji gibi konular sözde-bilimsel inançlara örnek olmakla beraber bu konular popüler medya üzerinden servis edilen ve geniş kitleleri etkileyebilen konulardır (Liu, 2009). Bununla birlikte bazı araştırmalarda da son yıllarda öğrencilerin sahip olduğu sözde-bilimsel inanışlarda artış yaşandığı dile getirilmektedir (Shein vd., 2014; Tseng vd., 2014). Genel olarak bilim okuryazarlı̆̆ ile aynı kavram olduğu düşünülen fen okuryazarlığı toplumlara bilimsel bakış açısı kazandırma açısından önemli bir faktör olduğu görülmektedir. Fen okuryazarı olabilen bireylerin kişisel ve toplumsal meselelerde karar verirken sorgulayıcı bir bakış açısıyla yeni açıklamalar üzerinde düşünebilmesi beklenmektedir. Söz konusu bilişsel yetkinliğin ve muhakemelerin olabilmesi için öncelikle argümantasyon sürecinin yaşanması gerekmektedir. $\mathrm{Bu}$ gerekçelerle, araştırmada, öğrencilerde bilim ve sözde-bilim ayrımı farkındalığını geliştirmek için argümantasyona dayalı öğrenme etkinliklerine yer verilmesi uygun görülmüştür.

$\mathrm{Bu}$ araştırmada sekizinci sınıf düzeyinde öğrenim gören öğrenciler ile karma araştırma yöntemi kullanılarak sözde-bilimsel inanışların derinlemesine incelenmesi ve bilim sözde-bilim ayrımının argümantasyon aracılığı ile geliştirilmesi amaçlanmaktadır.

$\mathrm{Bu}$ çalışmada karma araştırma yöntemlerinden yakınsayan paralel desen kullanılmıştır. Bu çalışmanın nicel boyutunda Mersin ili Akdeniz ilçesinde yer alan bir ortaokuldaki 8. sınıf düzeyinde öğrenim gören 32 öğrenci yer almaktadır. Kolay ulaşılabilir örnekleme yöntemiyle seçilen çalışma grubu, birinci araştırmacının görev yaptığı okulda ve bilim uygulamaları dersine girdiği sınıftan oluşmaktadır. Çalışma grubunda 18 erkek ve 14 kız öğrenci yer almaktadır.

Çalışmanın nicel boyutunda Çetinkaya ve Taşar (2018) tarafından geliştirilen ve araştırma kapsamında izin alınan Sözde-Bilim İnanış Ölçeği (SİÖ) kullanılmıştır. SïÖ, çalışmada argümantasyona dayalı öğretim sürecinin öncesinde ve sonrasında olmak üzere iki defa kullanılmıştır. Çalışmanın nitel boyutunda veri toplama aracı olarak 9 sorudan oluşan yarı yapılandırılmış görüşme formu kullanılmıştır. Veri analizinde nicel boyutta hem uygulanan ölçeğin geneli hem de alt boyutları için SPSS paket programı kullanılarak istatistiksel hesaplamalar yapılmıştır. Nitel verilerin analizinde içerik analizi yöntemine başvurulmuştur. Ayrıca bu kod ve temaların ilişkilerini gösteren matris ve şekiller hazırlanmıştır.

Uygulama öncesinde nicel ve nitel veri toplama aracı ile veriler toplanmıştır. Ardından haftada 2 ders saati olmak üzere 4 hafta boyunca sözde-bilim ile ilgili sınıf düzeyine uygun 4 konu (şifalı taşlar, refleksoloji, astroloji ve ufoloji) argümantasyon yöntemi kullanılarak ele alınmıştır. Her hafta bir konu sınıf ortamında argümantasyon yöntemi ile tartışılmıştır. Argümantasyon yöntemi doğrultusunda her tartışmadan önce gruplara ayrılan öğrencilere argümantasyon formu dağıtılmış ve sözde-bilim ile ilgili metinler okunduktan sonra formun doldurulması istenmiştir. Öğrencilerden formlarda, metinlerde yer alan bilimsel olan ve bilimsel olmayan bilgilerin belirlenmesi ve gerekçeleriyle tartışılarak yazılması istenmiştir. Formlara verilen cevapların paylaşılması istenmiştir. Bu doğrultuda tüm sınıfın katılımıyla 
bir argümantasyon süreci yürütülmüş̧ür. Tüm konular ele alındıktan sonra SİÖ ve görüşme formu süreç sonunda aynı öğrencilere tekrar uygulanmıştır.

Geçerlik ve güvenirlik kapsamında önemli noktalara dikkat edilmiştir. Öncelikle ölçeğin işlevselliğini test etmek adına asıl uygulama yapılmadan önce başka bir okulda öğrenim gören 54 öğrenci pilot uygulamaya dahil edilmiştir. Pilot uygulama sonucunda Cronbach alfa güvenirlik katsayısı değeri .88 olarak hesaplanmıştır. Ardından asıl uygulamada SïÖ 32 öğrenciye uygulandığında ölçeğin Cronbach alfa güvenirlik katsayısı değeri .78 olarak hesaplanmıştır. Çalışmanın nitel kısmında geçerlik, güvenirlik çalışmaları kapsamında yarı yapılandırılmış görüşme formu hazırlandıktan sonra uzman görüşüne sunulmuştur ve dönütler ışığında gerekli düzenlemeler yapılmıştır. Görüşme formunun pilot uygulaması 10 kişi ile yapılarak soruların işlevselliği test edilmiştir. Ayrıca görüşme transkriptlerinin analiz çalışmasına 3 puanlayıcı (2 araştırmacı, 1 bağımsız puanlayıcı) katılmıştır. Miles ve Huberman (1994, s. 64) tarafından önerilen uyum yüzdesi bu araştırmada \%85 düzeyinde bulunmuştur. Bununla birlikte transkriptlerin analizi sırasında bulguların doğruluğunu ve bütünlüğünü kontrol ettirmek amaciyla katılımcı teyidine başvurulmuştur. Ayrıca araştırmanın hem geçerlik ve güvenirliğe kanıt olması açısından hem de inandırıcılığı ve aktarılabilirliği sağlaması açısından katılımcıların görüşmelerde verdiği cevapların bazı bölümleri alıntılar halinde bulgular kısmında sunulmuştur.

Çalışmanın ilk boyutuna yönelik yapılan analizlerde uygulama öncesi ve sonrası sözde-bilimsel inanış ölçeğinden alınan puanlar açısından sözde-bilimsel inanışlarda cinsiyet faktörüne göre anlamlı bir farklılık bulunamamıştır. Sözde-bilimsel inanışların cinsiyete bağlı olmadı̆̆ 1 alanyazındaki bazı çalışmalarda görülmektedir (Berkant \& Ermeydan, 2017; Gül, 2016; Lundström, 2007, Şahin \& Uçar, 2018).

Araştırmanın ikinci boyutuna yönelik yapılan analizler sonucunda sözde-bilim inanış ölçeğinden öğrencilerin öğretim öncesi ve sonrası ölçek puanları arasında anlamlı bir farklılığın olduğu görülmektedir. Bu durumun tüm alt boyutlar için de geçerli olduğu söylenebilir. Nitel boyuttan elde edilen verilere göre de bilimsel bilginin özelliklerine ait düşünce ve bilgilerde son görüşmelerde ön görüşmelere göre artış gözlemlendiği söylenebilir. Bununla birlikte bilimsel olan ve bilimsel olmayan bilginin ayrımı noktasında da bir değişim ve gelişim olduğu sonucuna da varılmaktadır. Benzer şekilde öğrencilerin sözde-bilim algıları ön görüşmede çok yüzeysel iken son görüşmede sözde-bilim ile ilgili daha fazla fikir beyan edip örnekler verdiği görülmektedir. Diğer bir ifadeyle uygulanan argümantasyon yönteminin süreci olumlu yönde etkilediği sonucuna ulaşılabilir.

Araştırmanın üçüncü boyutu olan öğrencilerin bilimsel bilgiye ait ön görüşleri incelendiğinde öğrencilerin bilimsel bilgiyi genel olarak araştırma sonucu elde edilmiş, deneysel ve kanıtlanmış bilgi olarak gördügü söylenebilir. Gerek üniversite gerekse ortaokul öğrencilerinin bilimsel bilgiyi, daha çok kanıtlanma, deney-gözlem içerme ve uzman kişilerce ortaya atılma şeklinde tanımlaması ulaşılan sonucu destekler niteliktedir (Eş \& Turgut, 2018; Saka \& Sürmeli, 2017; Tatar vd., 2011; Turgut, 2009; Turgut vd., 2016). Ayrıca çalışmanın nitel boyutunda öğrencilerin sözde-bilimi kanıtlanmamış bilgiler olarak görmesi de bilimin kanıtlanabilir olması gerektiği görüşünü ortaya çıkarmaktadır.

Araştırmanın dördüncü boyutu olan öğrencilerin sözde-bilime dair görüşleri incelendiğinde argümantasyona dayalı öğretim öncesi ve sonrası görüşlerin öğrencilerin bilim sözde-bilim ayrımı ve bilimsellik algılarının süreç içerisinde bazı kategorilerde (sözde-bilimin özellikleri, batıl inanç vb.) geliştiği söylenebilir. Ancak son görüşmelerde iki öğrenci nazar ve burçlar batıl inanç olsa da bu konular ile hala ilgilendiğini belirtmiştir. Bu noktada yapılan öğretimin tam anlamıla sözde-bilim algısını bertaraf edemediği söylenebilir. Bu sebeple daha uzun süreli ya da daha farklı öğretim metotlarının kullanılması ve etkililiğinin test edilmesi tavsiye edilebilir. 